\title{
Effect of composition on coagulation, curd firming, and syneresis of goat milk
}

\author{
Giorgia Stocco, ${ }^{*}$ Michele Pazzola, ${ }^{* 1}$ Maria L. Dettori, ${ }^{*}$ Pietro Paschino, ${ }^{*}$ Giovanni Bittante, $\dagger$ \\ and Giuseppe M. Vacca* \\ *Department of Veterinary Medicine, University of Sassari, via Vienna 2, 07100 Sassari, Italy \\ †Department of Agronomy, Food, Natural Resources, Animals and Environment (DAFNAE), University of Padova, viale dell'Università 16, \\ 35020 Legnaro (PD), Italy
}

\begin{abstract}
The present study investigated the effect of different levels of fat, protein, and casein on (1) traditional milk coagulation properties, and (2) curd firming over time parameters of 1,272 goat milk samples. Relationships between fat, protein, and casein and some indicators of udder health status (lactose, $\mathrm{pH}$, somatic cells, bacterial count, and $\mathrm{NaCl}$ ) were also investigated. Traditional milk coagulation properties and modeled curd-firming parameters were analyzed using a mixed model that considered the effect of days in milk, parity, farm, breed, the pendulum of the instrument, and different levels of fat, protein, and casein. Fat, protein, and casein were also tested with the same model but one at a time. Information provided by this model demonstrated the effect of one component alone, without contemporarily considering that of the others. The results allowed us to clarify the effect of the major milk nutrients on coagulation, curd firming, and syneresis ability of goat milk. In particular, milk rich in fat was associated with better coagulation properties, whereas milk rich in protein was associated with delayed coagulation. The high correlation of fat with protein and casein contents suggests that the effect of fat on the cheese-making process is also attributable to the effects of protein and casein. When only protein or only casein was included in the statistical model, the pattern of coagulation, curd firming, and syneresis was almost indistinguishable. The contemporary inclusion of protein and casein in the statistical model did not generate computing problems and allowed us to better characterize the role of protein and casein. Consequently, given their strong association, we also tested the effect of casein-to-protein ratio
\end{abstract}

\footnotetext{
Received May 7, 2018.

Accepted July 1, 2018

${ }^{1}$ Corresponding author: pazzola@uniss.it
}

(i.e., casein number). Higher values of casein number led to a general improvement in the coagulation ability of milk, suggesting that casein-to-protein ratio, not just protein or casein, should be considered when milk is destined for cheese making. These results are especially useful for dairy farmers who want to increase their profits by improving the technological quality of the milk produced.

Key words: fat, protein, casein, casein number, caprine

\section{INTRODUCTION}

The evaluation of goat milk quality is of fundamental economic importance, especially in those countries where the goat sector is well developed and the system of quality payment is based mainly on protein and fat contents. That payment system determines the basic price of milk according to its quality, and bonus or penalties are applied to goat farmers in relation to each parameter (component of the milk) included in the price equation (Pirisi et al., 2007).

The main use of goat milk is in cheese making (Boyazoglu and Morand-Fehr, 2001); milk fat and protein, in particular casein, are the major contributors to cheese yield and they also affect milk coagulation properties (Cecchinato and Bittante, 2016).

The hygienic control of milk (i.e., bacterial and somatic cell counts) is related to the quality payment system. When an inflammatory process affects the mammary gland, the flow of milk constituents from blood to the lumen is modified because of the different osmotic pressure (lactose, minerals) and because of the increased leakage of materials (somatic cells, bacteria); hence, the milk composition can change (Poulsen et al., 2015), but these aspects need to be further studied in goat species.

During the last decades, the goat production system has changed considerably in order to increase milk yield. Herd and feeding management have been standardized (Clark and Mora García, 2017) and lo- 
cal breeds replaced with specialized ones (Pirisi et al., 2007). In Sardinia, those strategies have led to a general decrease of fat and protein contents in milk (Vacca et al., 2016). Because large differences are detectable among goat breeds in terms of milk composition (Vacca et al., 2018a) and cheese-making efficiency (Vacca et al., 2018b), new knowledge about the effect of goat milk composition on the renneting properties could provide useful information for farmers and dairy plants.

Milk coagulation properties (MCP) are generally measured using a lactodynamograph (McMahon and Brown, 1982), and 3 single-point traits are recorded: rennet coagulation time (RCT, min); curd firming rate, measured as the time to a curd firmness of 20 $\mathrm{mm}\left(\mathbf{k}_{\mathbf{2 0}}, \mathbf{m i n}\right)$; and curd firmness, often measured 30 min after enzyme addition $\left(\mathbf{a}_{\mathbf{3 0}}, \mathbf{m m}\right)$. When the curd firming process is extended until $60 \mathrm{~min}$ of analysis, curd firmness values after 45 and $60 \mathrm{~min}$ are recorded $\left(\mathbf{a}_{45}\right.$, and $\left.\mathbf{a}_{60}, \mathrm{~mm}\right)$. Recently, the modeling of the curd firming process over time $\left(\mathbf{C F}_{\mathbf{t}}\right.$; Bittante et al., 2013) has been used to study, in depth, the coagulation ability of milk from small ruminants (Bittante et al., 2013; Vacca et al., 2015; Pazzola et al., 2018). That method provides 4 equation parameters: the asymptotic potential value of curd firmness at an infinite time $\left(\mathbf{C F}_{\mathbf{P}}\right.$, $\mathrm{mm})$, the curd firming instant rate constant $\left(\mathbf{k}_{\mathrm{CF}}, \% /\right.$ $\mathrm{min}$ ), the RCT predicted from the modeling of all available data $\left(\mathbf{R C T}_{\mathbf{e q}}, \mathbf{m i n}\right)$, and the syneresis instant rate constant $\left(\mathbf{k}_{\mathbf{S R}}, \% / \min \right)$; and 2 derived traits: maximum curd firmness $\left(\mathbf{C F}_{\max }, \mathbf{m m}\right)$ achieved after a given time interval $\left(\mathbf{t}_{\max }, \min \right)$.

Based on the available literature, no study has so far investigated the relationships among milk composition traits and their effects on single-point and modeled coagulation parameters in goat milk. For these reasons, the present research was carried out to quantify the effect of the major milk components (fat, protein, and casein) directly on traditional $\mathrm{MCP}$ and $\mathrm{CF}_{\mathrm{t}}$ parameters of goat milk, and to study their relationship with some udder health traits (lactose, $\mathrm{pH}, \mathrm{SCC}$, bacterial count, and $\mathrm{NaCl}$ ).

\section{MATERIALS AND METHODS}

\section{Milk Sampling and Analysis}

A total of 1,272 goats belonging to 6 breeds, reared in 35 farms distributed over the island of Sardinia (Italy) were sampled once for milk composition. Details of farm characteristics and description of the breeds are reported by Vacca et al. (2018a).

Milk fat, protein, casein, $\mathrm{NaCl}$, lactose, and $\mathrm{pH}$ were analyzed using a MilkoScan FT6000 milk analyzer
(Foss Electric A/S, Hillerød, Denmark), calibrated according to FIL-IDF guidelines (ISO-IDF, 2013); casein number was calculated as the casein-to-protein ratio multiplied by 100; SCC was determined by a Fossomatic 5000 somatic cell counter (Foss Electric A/S) and transformed to the logarithmic $\left[\log _{2}\left(\mathrm{SCC} \times 10^{-5}\right)+3\right]$ somatic cell score; total bacterial count was determined by a BactoScan FC150 analyzer (Foss Electric A/S) and transformed into the logarithmic bacterial count $\left[\log _{10}(\right.$ total bacterial count/1,000)].

\section{Analysis of MCP}

A lactodynamograph instrument (Formagraph, Foss Italia s.p.a., Padova, Italy) was used to assess MCP. Rennet (Hansen Naturen Plus 215, Pacovis Amrein AG, Bern, Switzerland) was diluted in distilled water to obtain a solution of $1.2 \%$ (wt/vol), with a final value of international milk clotting units (IMCU) of 0.0513 $\mathrm{IMCU} / \mathrm{mL}$ of milk. The single-point recorded MCP were RCT (min), $\mathrm{k}_{20}(\mathrm{~min})$, and $\mathrm{a}_{30}, \mathrm{a}_{45}$, and $\mathrm{a}_{60}(\mathrm{~mm})$.

\section{Modeling the Curd-Firming Process of Goat Milk}

During lactodynamographic analysis, the Formagraph records, every $15 \mathrm{~s}$, the width $(\mathrm{mm})$ of the oscillatory graph of the pendula immerged in the wells filled with milk samples after rennet addition. Consequently, during a 60-min test, 240 individual point observations of curd firming are recorded for each individual milk sample. Extending the length of lactodynamographic test allowed us to observe differences in the $\mathrm{CF}_{\mathrm{t}}$ pattern of individual goats using a 4-parameter model (Bittante et al., 2013):

$$
C F_{t}=C F_{P} \times\left[1-e^{-k_{C F} \times\left(t-R C T_{e q}\right)}\right] \times e^{-k_{S R} \times\left(t-R C T_{e q}\right)},
$$

where $C F_{t}$ is curd firmness at time $t(\mathrm{~mm}) ; C F_{P}$ is the asymptotical potential value of $\mathrm{CF}$ at an infinite time in absence of syneresis $(\mathrm{mm}) ; k_{C F}$ is the curd-firming instant rate constant $(\% / \mathrm{min}) ; k_{S R}$ is the syneresis instant rate constant (\%/min); and $R C T_{e q}$ is RCT estimated by $\mathrm{CF}_{\mathrm{t}}$ equation on the basis of all data points (min).

\section{Statistical Analysis}

To avoid convergence and estimation problems, the procedure by Bittante et al. (2013) was modified according to Cipolat-Gotet et al. (2018) to include CF measurements up to $45 \mathrm{~min}$ from the addition of rennet (180 records for each individual milk sample, 1 every 
$15 \mathrm{~s})$. The asymptotical $\mathrm{CF}_{\mathrm{P}}$ was calculated as reported in Pazzola et al. (2018) and the other $3 \mathrm{CF}_{\mathrm{t}}$ model parameters $\left(\mathrm{RCT}_{\text {eq }}, \mathrm{k}_{\mathrm{CF}}\right.$, and $\left.\mathrm{k}_{\mathrm{SR}}\right)$ were estimated by a curvilinear regression using the PROC NLIN of SAS software (SAS Institute Inc., Cary, NC; version 9.4, 2013). The parameters of each individual equation were estimated using the Marquardt iterative method (350 iterations and a $10^{-5}$ level of convergence) according to Bittante (2011).

Resulting parameters from coagulation modeling were then analyzed using a MIXED procedure (SAS Institute Inc., Cary, NC), according to the following model:

$$
\begin{gathered}
Y_{\text {efghilmn }=\mu}+\text { DIM }_{e}+\text { Parity }_{f}+\text { Fat }_{g}+\text { Protein }_{h} \\
+ \text { Casein }_{i}+\text { Farm }_{l}+\text { Breed }_{m}+\text { Pendulum }_{n} \\
+e_{\text {efghilmn }},
\end{gathered}
$$

where $Y_{\text {efghilmn }}$ is the observed trait; $\mu$ is the overall intercept of the model; $D I M_{e}$ is the fixed effect of the eth class of days in milk ( $e=1$ to 4; class 1: $<80 \mathrm{~d}$ (329 goats); class 2: 81-120 d (350 goats); class 3: 121-160 d (352 goats); class 4: >160 d (241 goats); Parity $_{f}$ is the fixed effect of the $f$ th parity $[f=1$ to 3 ; class 1 : first and second (392 samples); class 2: third and fourth (460 samples); class 3: $\geq$ fifth (420 samples)]; Fat $t_{g}$ is the fixed effect of the $g$ th class of fat percentage $(g=1$ to 7 ; class $1:<2.79$; class 2: 2.79-3.50; class 3: $3.51-4.23$; class 4 : 4.24-4.96; class 5: 4.97-5.68; class 6: 5.69-6.40; class 7: $>6.40$ ); Protein $h$ is the fixed effect of the $h$ th class of protein percentage $(h=1$ to 7 ; class $1:<2.93$; class 2 : 2.93-3.19; class 3: 3.20-3.47; class 4: 3.48-3.75; class 5: 3.76-4.03; class 6: 4.04-4.30; class 7: >4.30); Casein $_{i}$ is the fixed effect of the $i$ th class of casein percentage $(i=$ 1 to 7 ; class 1: $<2.19$; class 2: 2.19-2.44; class 3: $2.45-$ 2.71 ; class 4 : $2.72-2.98$; class 5 : $2.99-3.24$; class 6 :
3.25-3.51; class 7: >3.51); Farm $_{l}$ is the random effect of the $l$ th farm $(l=1$ to 35$) ;$ Breed $_{m}$ is the random effect of the $m$ th breed $(m=$ Saanen, Camosciata delle Alpi, Murciano-Granadina, Maltese, Sarda, and Sarda Primitiva); Pendulum ${ }_{n}$ is the random effect of the $n$th pendulum of the Formagraph instrument ( $n=1$ to 10$)$; and $e_{\text {efghilmn }}$ is the random residual $\sim N\left(0, \sigma_{e}^{2}\right)$, where $\sigma$ is the standard deviation. Each of the 7 classes of fat, protein, and casein were designed based on distribution of the variables: each single class explained $0.5 \mathrm{SD}$ of the variable, the fourth was centered on the mean value, and the first and the seventh values represented the tails of the distribution.

A further model derived from model [1] was later used to test fat, protein, and casein one at a time. Results from this model, named model [2], indicate the effect of one component alone, without contemporarily considering that of the others. Orthogonal polynomial contrasts (linear, quadratic, and cubic patterns) were estimated between least squares means of fat, protein, and casein traits. Pearson product-moment correlations were performed between milk composition traits and udder health parameters.

\section{RESULTS}

Descriptive statistics of milk composition traits and results from Pearson product-moment correlations between milk traits and udder health traits are reported in Table 1. Milk protein and casein were very strongly correlated with each other and highly correlated with fat content. All the 3 major milk components were weakly correlated with milk lactose content, $\mathrm{pH}$, and bacterial count, and lowly to moderately correlated with SCS (positively; i.e., unfavorably) and with $\mathrm{NaCl}$

\begin{tabular}{|c|c|c|c|c|c|c|c|c|}
\hline \multirow[b]{2}{*}{ Item } & \multicolumn{3}{|c|}{ Milk composition } & \multicolumn{5}{|c|}{ Udder health traits } \\
\hline & Fat, $\%$ & Protein, \% & Casein, $\%$ & Lactose, $\%$ & $\mathrm{pH}$ & SCS & $\mathrm{LBC}^{1}$ & $\mathrm{NaCl}, \mathrm{mg} / 100 \mathrm{~mL}$ \\
\hline $\mathrm{SD}$ & 1.47 & 0.6 & 0.55 & 0.33 & 0.12 & 2.02 & 0.81 & 58 \\
\hline Minimum & 1.37 & 2.36 & 1.63 & 1.07 & 5.45 & 0.44 & 0.30 & 98 \\
\hline Maximum & 9.94 & 7.36 & 5.47 & 5.45 & 7.17 & 11.19 & 4.23 & 702 \\
\hline \multicolumn{9}{|l|}{ Correlation } \\
\hline Casein, \% & & & - & -0.01 & $-0.19^{* * *}$ & $0.29^{* * *}$ & $0.06^{*}$ & $-0.41^{* * *}$ \\
\hline
\end{tabular}
content (negatively).

Table 1. Descriptive statistics and Pearson product-moment correlations between individual milk quality traits and udder health traits in goat milk samples $(\mathrm{n}=1,272)$

${ }^{1} \log _{10}($ total bacterial count $/ 1,000)$.

${ }^{*} P<0.05 ;{ }^{* *} P<0.01 ;{ }^{* * *} P<0.001$. 
Table 2. Analysis of variance for traditional milk coagulation properties (MCP) and curd firming over time $\left(\mathrm{CF}_{\mathrm{t}}\right)$ parameters of individual milk samples (n $=1,272)$, with $F$-value and significance for fixed effects and the proportion of variance (in percentage) explained by random effects

\begin{tabular}{|c|c|c|c|c|c|c|c|c|c|}
\hline \multirow[b]{2}{*}{ Trait } & \multicolumn{5}{|c|}{ Fixed effects } & \multicolumn{3}{|c|}{ Random effects } & \multirow[b]{2}{*}{$\mathrm{RMSE}^{1}$} \\
\hline & DIM & Parity & Fat & Protein & Casein & Farm & Breed & Pendulum & \\
\hline \multicolumn{10}{|c|}{ Traditional $\mathrm{MCP}^{2}$} \\
\hline $\mathrm{RCT}, \min$ & $8.09^{* * *}$ & 1.83 & $4.17^{* * *}$ & $2.94^{* *}$ & 0.78 & 30.3 & 1.0 & 0.4 & 3.62 \\
\hline $\mathrm{k}_{20}, \min$ & 2.34 & 2.17 & 1.93 & 2.00 & 1.19 & 31.4 & 0.7 & 1.9 & 2.29 \\
\hline $\mathrm{a}_{30}, \mathrm{~mm}$ & $3.37^{*}$ & $4.85^{* * *}$ & 0.99 & 0.62 & $2.79^{*}$ & 45.2 & 0.0 & 2.8 & 8.12 \\
\hline $\mathrm{a}_{45}, \mathrm{~mm}$ & 1.78 & $8.33^{* * *}$ & 1.5 & 0.92 & 1.66 & 43.3 & 0.0 & 7.9 & 8.23 \\
\hline $\mathrm{RCT}_{\mathrm{eq}}, \min$ & $4.98^{* *}$ & 1.77 & $4.91^{* * *}$ & $4.36^{* * *}$ & 0.55 & 22.8 & 1.8 & 0.2 & 4.55 \\
\hline $\mathrm{k}_{\mathrm{CF}}, \% / \mathrm{min}$ & $6.43^{* *}$ & 2.04 & $2.66^{*}$ & 0.75 & 0.65 & 25.2 & 0.0 & 12.8 & 7.31 \\
\hline $\mathrm{k}_{\mathrm{SR}}, \% / \mathrm{min}$ & 1.23 & 0.31 & 1.64 & 0.82 & 0.83 & 22.0 & 0.0 & 14.2 & 0.49 \\
\hline $\mathrm{CF}_{\mathrm{P}}, \mathrm{mm}$ & 2.26 & $13.18^{* * *}$ & 1.46 & 1.21 & $4.13^{* * *}$ & 50.6 & 0.0 & 4.5 & 7.20 \\
\hline $\mathrm{CF}_{\max }, \mathrm{mm}$ & 2.26 & $13.18^{* * *}$ & 1.46 & 1.21 & $4.13^{* * *}$ & 50.6 & 0.0 & 4.5 & 6.37 \\
\hline $\mathrm{t}_{\max }, \min$ & $6.54^{* * *}$ & 1.52 & $3.81^{* * *}$ & 1.35 & 0.6 & 22.0 & 1.5 & 7.6 & 10.08 \\
\hline
\end{tabular}

${ }^{1} \mathrm{RMSE}=$ root means square error.

${ }^{2} \mathrm{RCT}=$ rennet coagulation time of samples coagulating within 60 min of enzyme addition; $\mathrm{k}_{20}=$ curd-firming time of samples reaching $20 \mathrm{~mm}$ of firmness within 60 min from enzyme addition; $\mathrm{a}_{30}, \mathrm{a}_{45}, \mathrm{a}_{60}=$ curd firmness at 30, 45, and 60 min, respectively, after enzyme addition.

${ }^{3} \mathrm{RCT}_{\mathrm{eq}}=$ rennet coagulation time estimated using the $\mathrm{CF}_{\mathrm{t}}$ equation; $\mathrm{k}_{\mathrm{CF}}=$ curd-firming instant rate constant; $\mathrm{k}_{\mathrm{SR}}=$ syneresis instant rate constant; $\mathrm{CF}_{\mathrm{P}}=$ asymptotic potential curd firmness; $\mathrm{CF}_{\max }=$ maximum curd firmness attained within 45 min; $\mathrm{t}_{\max }=$ time at attainment of $\mathrm{CF}_{\max }$. ${ }^{*} P<0.05 ;{ }^{* *} P<0.01 ;{ }^{* * *} P<0.001$.

\section{Effect of Individual Animal Factors, Farm, and Breed on Renneting Properties of Goat Milk}

The ANOVA for traditional $\mathrm{MCP}$ and $\mathrm{CF}_{\mathrm{t}}$ parameters of individual milk samples are summarized in Table 2. The effects of animal factors (DIM, parity, and breed) and farm were included in the statistical model to correct the estimation for the effect of milk composition on coagulation, curd firming, and syneresis processes. In the present study, these are reported only in the results because they have been discussed in depth in previous studies on the same data set (Vacca et al., 2018a; Pazzola et al., 2018). Briefly, DIM affected almost all coagulation traits. The coagulation process shortened with DIM: from the first to the last class of DIM, RCT and $\mathrm{RCT}_{\text {eq }}$ were reduced by about $1 \mathrm{~min}$, and time for achievement of $\mathrm{CF}_{\max }$ was shortened by about 5 min. This was mostly due to the increase in $\mathrm{k}_{\mathrm{CF}}$ during lactation, leading to higher $\mathrm{CF}_{\mathrm{P}}$ and $\mathrm{CF}_{\max }$ (data not shown). Parity affected curd firmness traits and $\mathrm{k}_{\mathrm{CF}}$. Milk from younger goats (first- and second-parity goats) was characterized by steeper $\mathrm{k}_{\mathrm{CF}}$ than milk from goats of parity 3 or older, with higher potential $\left(\mathrm{CF}_{\mathrm{P}}\right)$ and maximum $\left(\mathrm{CF}_{\max }\right)$ curd firmness (data not shown).

Among random effects (Table 2), breed variance was very low for MCP (from 0.0 to $1.0 \%$ of the total variance) and $\mathrm{CF}_{\mathrm{t}}$ parameters (from 0.0 to $1.8 \%$ ) when the model included milk composition traits, whereas the proportion of variance due to farm was much higher (from 22.0 to $70.8 \%$ of the total variance).

\section{Effect of Milk Composition on Renneting Properties of Goat Milk}

The effects of milk nutrient components on the examined traits (least squares means) are reported in Table 2. Increasing fat content shortened coagulation and curd firming times (Table 3 ) and affected $\mathrm{a}_{45}$ and $\mathrm{a}_{60}$ with a cubic trend. With regard to $\mathrm{CF}_{\mathrm{t}}$ parameters, $\mathrm{RCT}_{\mathrm{eq}}$ and $\mathrm{t}_{\max }$ values were reduced whereas $\mathrm{k}_{\mathrm{CF}}$ increased across classes of fat content.

Increasing protein content extended rennet coagulation time (both traditional and estimated from the modeling) and affected $\mathrm{k}_{20}$ with a quadratic trend (Table 4), whereas an increasing amount of casein was responsible for higher curd firmness parameters (Table $5)$.

\section{DISCUSSION}

\section{Contribution of Fat}

Research on the relationships between milk components and coagulation properties for goat milk were published in the 1980s but involved a very limited number of animals (Storry et al., 1983; Ambrosoli et al., 1988). A larger number of goats were sampled in a later study describing the influence of different genotypes of casein genes on milk coagulation properties (Caravaca et al., 2011).

In 2 previous studies of the present project that focused on the effect of 6 breeds of goat on $\mathrm{MCP}$ and $\mathrm{CF}_{\mathrm{t}}$ 
COAGULATION, CURD FIRMING, AND SYNERESIS OF GOAT MILK
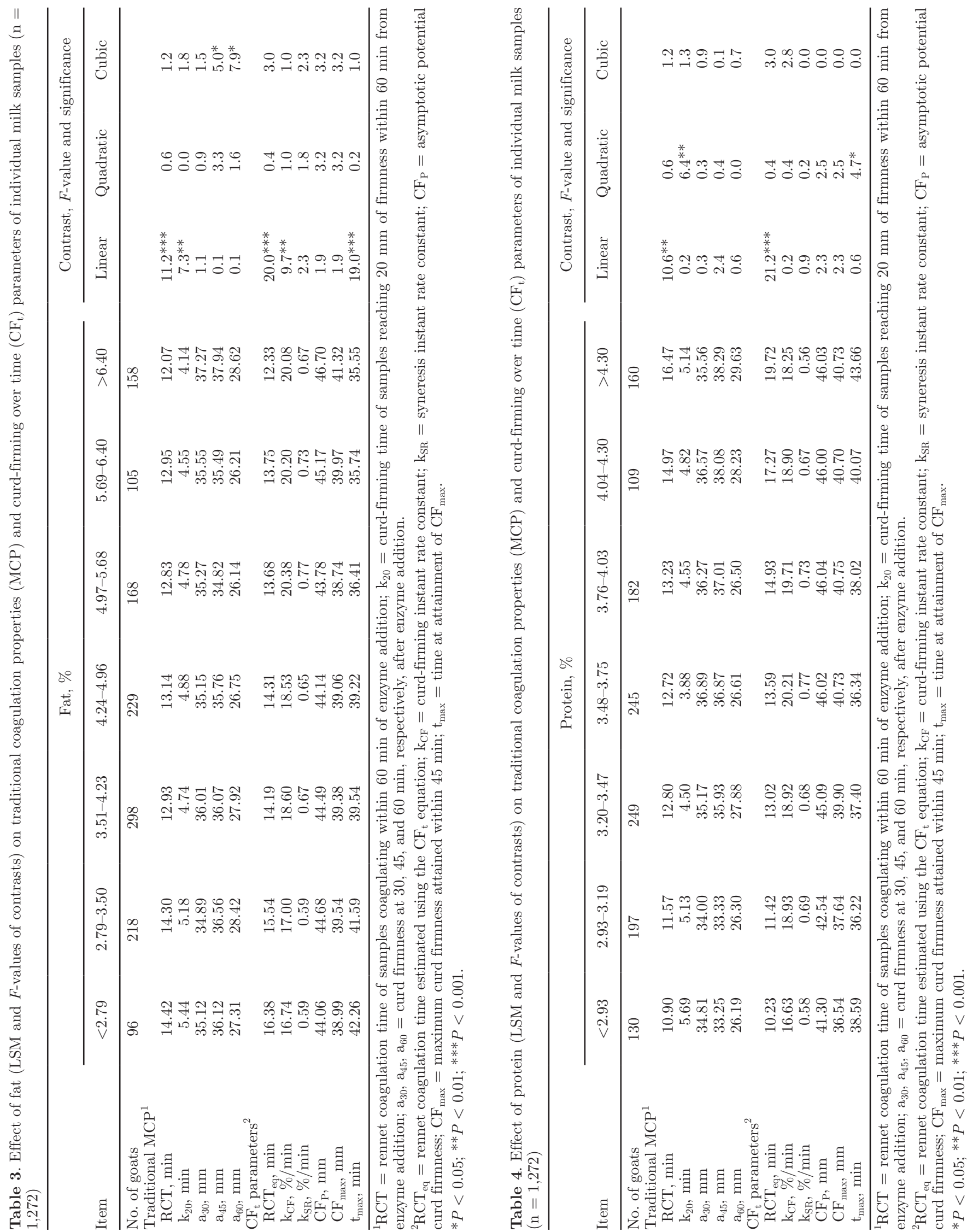
parameters (Vacca et al., 2018a; Pazzola et al., 2018), we divided the overall effect of breed on these traits. The direct (independent from milk yield and composition) and indirect (due to differences among breeds in milk yield and composition) effects of breed were compared in most previous studies. Those results showed that large differences among breeds in terms of daily milk yield did not explain differences in coagulation traits, whereas large differences in terms of fat (especially on CF traits and $\mathrm{k}_{\mathrm{CF}}$ rate) and protein (especially on $\mathrm{RCT}_{\text {eq }}$ and $\mathrm{t}_{\max }$ traits) contents explained a large part of the breed differences (indirect breed effect). The importance of breed (breed variance expressed as percentage of total variance) was small (Table 2) when milk composition was included in the statistical model in the current study. As far as we know, no previous studies have investigated the close connections between single milk components and coagulation parameters in goat species within breed.

A positive weak correlation was found between fat and lactose, perhaps because both are synthesized from glucose (Oftedal and Iverson, 1995). Fat was weakly negatively correlated with $\mathrm{pH}$, and this result could be explained by lipolysis. Spontaneous lipolysis occurs at natural milk $\mathrm{pH}$ and is correlated with activity of lipoprotein lipase, which is bound to the fat globules in goat species (Chilliard et al., 2003).

Goat milk is produced mainly by apocrine secretion, which results in a large number of cytoplasmic particles (similar in size to somatic cells) and epithelial cells in the milk (Park and Haenlein, 2013). Bagnicka et al. (2011) report that about 33\% of total SCC in healthy goats' mammary gland is due to cytoplasmic particles together with fat. Even though cytoplasmic particles and epithelial cells are not fully differentiated when using an automatic cell counter instead of staining methods (Pazzola et al., 2012), as in this study, results from the literature confirm the linear and positive correlation that we found between fat content and SCS (Table 1). The negative relationship between fat and $\mathrm{NaCl}$ was expected because of the osmotic properties of $\mathrm{NaCl}$ toward the other milk constituents. As reported in Table 3, high fat contents were associated with faster coagulation of milk. A graphical representation of curdfirming pattern combining the effect of different $\mathrm{CF}_{\mathrm{t}}$ parameters (Figure 1a) allows us to better appreciate in which specific phase fat content affects the cheesemaking process. Fat content enhanced coagulation by shortening $\mathrm{RCT}_{\mathrm{eq}}$ and increasing $\mathrm{k}_{\mathrm{CF}}$, so that a steeper pattern of the curve led to a faster attainment of $\mathrm{CF}_{\max }$.

The positive effect of fat on $\mathrm{RCT}_{\mathrm{eq}}$ is generally known because milk flocculation occurs due to the collision and aggregation of fat droplets (Huppertz and Kelly, 2006). However, in addition to the content of fat affect- 
ing the technological properties of milk, the physicochemical properties of the milk fat globules also have an effect (Huppertz and Kelly, 2006). The effect on $\mathrm{k}_{\mathrm{CF}}$ can be clarified by the amount of fat entrapped in the casein network. The fat globules coating caseins behave, to some extent, like casein micelles, accelerating the kinetics of coagulation (Sweetsur and Muir, 1983) but limiting the contraction of the casein matrix (Fox et al., 2017). Curd firmness traits $\left(\mathrm{a}_{45}\right.$ and $\left.\mathrm{a}_{60}\right)$ were influenced by the concentration of fat (cubic trend) but to a lesser extent than $\mathrm{RCT}_{\mathrm{eq}}$ and $\mathrm{k}_{\mathrm{CF}}$.

If included alone in the statistical model (without the contemporary presence of protein and casein), fat content was not able to shorten RCT but did distinctly
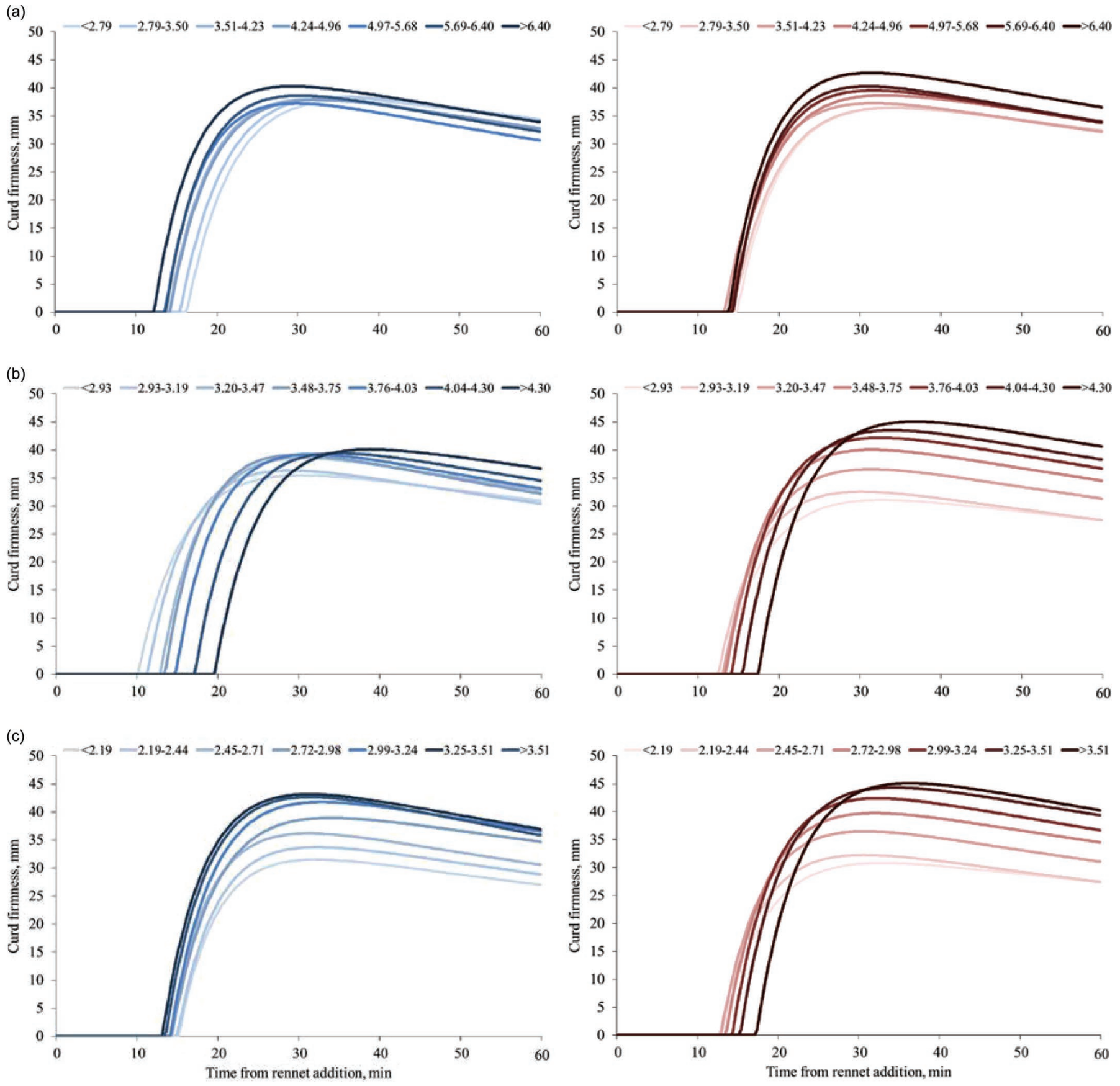

Figure 1. Pattern of curd firmness after rennet addition (curd firming over time parameters, $\mathrm{CF}_{\mathrm{t}}$ ) according to classes of fat (a), protein (b), and casein (c) using model 1 (left panels, blue) and model 2 (right panels, red). Color version available online. 
increase curd firmness traits (Figure 1a, right panels, red). The interpretation of these last results should take into account the high correlation of fat content with protein and casein contents. When fat content is seen to affect cheese making, it includes the correlated effects of protein and casein contents. This also explains apparent contradictions with previous studies in other ruminants (Cipolat-Gotet et al., 2013; CaballeroVillalobos et al., 2018) and confirms the need to include protein and casein contents in models when studying effects of fat.

\section{Contributions of Protein and Casein}

In addition to the osmotic properties of lactose, $\alpha$-LA could play a controlling role in lactose formation, in particular when the synthesis of $\alpha$-LA ends. Then, the remaining protein in the gland is secreted and lactose synthesis stops (Brew and Campbell, 1967), explaining the negative correlation between protein and lactose (Table 1). The release of hydrogen ions during the synthesis of casein micelles (Fox et al., 2017) may explain the significant negative correlations found for both protein and casein with milk $\mathrm{pH}$. The positive relationships between protein and casein with SCS can likely be explained as for fat content, and might be due to the type of secretion in goats. When bacterial infection occurs, physico-chemical damage to the milk is observed, particularly involving proteolysis of casein and micelle properties (Leitner et al., 2006). The weak but significant correlations between protein and casein with logarithmic bacterial count could be explained in part by the involvement of bacteria and bacterial proteases and in part by the multiple and complex changes in casein micelle morphology and protein structure (Leitner et al., 2006). Similar to lactose, the negative correlation between protein and casein with $\mathrm{NaCl}$ can be justified by osmotic conditions.

The interpretation problem due to correlations between milk components is larger for protein and casein than between the other traits. Because caseins are the major contributors to milk protein content, their correlation with protein content is very large (99\%). This explains why, when only protein or only casein is included in the statistical model, the resulting graphical representations of coagulation, curd firming, and syneresis pattern are almost identical (and partly overlapped with the effect of fat). Despite their strong association, their contemporary inclusion in the statistical model did not generate computing problems and allowed us to better characterize the role of protein and casein. An increase in CP content (at constant casein content) caused a delay of coagulation, whereas an increase in casein content (at constant CP content) caused an increase of curd firming rate and the achievement of greater curd firmness, as can be seen in Figure 1. The syneresis rate, $\mathrm{k}_{\mathrm{SR}}$, was not much affected by milk composition (Table 2).

Comparison of our results with the literature is not easy because there are few specific works on goat milk, and studies on other species normally consider only protein or only casein. In contrast to the effect of fat, coagulation time increased markedly with increasing concentration of protein content. Figure $1 \mathrm{~b}$ shows that the coagulation process of goat milk was delayed because of a longer $\mathrm{RCT}_{\text {eq }}$ in milk samples with high protein content. As the concentration of rennet was not adjusted to the protein content of milk, this effect could be attributed in part to the decreasing rennet-tocasein ratio, which results in the need for more time to generate sufficient hydrolysis of $\kappa$-casein to induce aggregation of para-casein micelles (Fox et al., 2017). For cow milk destined for cheese manufacture, a minimum protein level of 2.5 to $3.0 \%$ is necessary to achieve gel formation within 40 to $60 \mathrm{~min}$; because the maximum gel firming rate and gel firmness increase more than proportionally with protein content, small variations in protein level are sufficient to exert quite a large effect on rennet coagulation properties (Guinee et al., 1997). On the other hand, goat milk casein increased only curd firmness traits (Figure 1c). In fact, caseins play a fundamental role not only during the gelation process, but also after coagulation. All casein micelles are freely dispersed in the serum and can aggregate randomly, but once the gel matrix has started to form, free micelles may react with the matrix or with other free micelles. Therefore, the properties of the final gel network may be affected considerably by the quantity of casein at the RCT (Fox et al., 2017), in agreement with the results found in this study.

\section{Contribution of Casein Number}

Given the high correlation between protein and casein (Table 1) and to better understand their effect, we decided to test casein number in model [2] (to avoid multicollinearity problems, we did not include it in model [1]). The ratio of casein to total protein has never been investigated before in goat milk in relation to coagulation traits, even if casein-to-total protein ratio is related to cheese yield.

In this study, casein number modified all coagulation traits except for coagulation time (Supplemental Table S1; https://doi.org/10.3168/jds.2018-15027). Higher values of casein number led to a general improvement in the coagulation ability of milk (Supplemental Figure S1; https://doi.org/10.3168/jds.2018-15027). Weak and erratic modifications were observed in the speed of curd 
firming and syneresis rates, which seem to be more affected by the genetics of the goat and to a lesser extent by its milk quality (Pazzola et al., 2018).

It is clear that a better interpretation of coagulation, curd firming, and syneresis pattern depends on knowledge of the content of individual protein fractions analysis and of their genetic variants. The genetic variants of goat caseins have been studied in depth (Vassal et al., 1994; Caravaca et al., 2011) but the content of different protein fractions in milk much less so (Clark and Mora García, 2017). Little is known about the simultaneous effect of both on cheese-making traits, so this will be an important field of research for improving our knowledge on mechanisms of cheese making in goat species.

\section{CONCLUSIONS}

These results allowed us to quantify the effect of the major milk nutrients on coagulation, curd firming, and syneresis ability of goat milk. Milk rich in fat was associated with better coagulation properties, whereas milk rich in protein was associated with delayed coagulation and a large quantity of casein, with improved renneting ability of milk only once coagulation began (i.e., curd firmness). However, for milk destined for cheese making, casein-to-protein ratio should be considered in addition to amount of protein or casein alone. Our results provide useful information for dairy farmers who want to increase their profits by improving milk quality. However, further studies are needed to investigate other effects (e.g., udder health traits, the content of protein fractions, and genetic variants) on milk composition, coagulation properties, and cheese-making efficiency of goats.

\section{ACKNOWLEDGMENTS}

This research was supported by the Regional Government of Sardinia (Legge Regionale 7/2007; CUP J72I15000030007). The authors thank the farmers for providing access to their flocks; the AIPA/APA (provincial farmer associations) of Cagliari, Nuoro, Sassari, and Oristano (Italy) and the firms Sepi Forrmaggi (Marrubiu, Italy) and L'Armentizia Moderna (Guspini, Italy) for their support in sample collection; and A. R. A. Sardegna (regional farmer association of Sardinia) for support in milk chemical analysis.

\section{REFERENCES}

Ambrosoli, R., L. Di Stasio, and P. Mazzocco. 1988. Content of as1casein and coagulation properties in goat milk. J. Dairy Sci. 71:2428.
Bagnicka, E., A. Winnicka, A. Jóźwik, M. Rzewuska, N. Strzałkowska, E. Kościuczuk, B. Prusak, J. Kaba, J. Horbańczuk, and J. Krzyżewski. 2011. Relationship between somatic cell count and bacterial pathogens in goat's milk. Small Rumin. Res. 100:72-77.

Bittante, G. 2011. Modeling rennet coagulation time and curd firmness of milk. J. Dairy Sci. 94:5821-5832.

Bittante, G., B. Contiero, and A. Cecchinato. 2013. Prolonged observation and modelling of milk coagulation, curd firming, and syneresis. Int. Dairy J. 29:115-123.

Boyazoglu, J., and P. Morand-Fehr. 2001. Mediterranean dairy sheep and goat products and their quality. A critical review. Small Rumin. Res. 40:1-11.

Brew, K., and P. N. Campbell. 1967. Studies on the biosynthesis of protein by lactating guinea-pig mammary gland. Characteristics of the synthesis of $\alpha$-lactalbumin and total protein by slices and cell-free systems. Biochem. J. 102:265-274.

Caballero-Villalobos, J., J. M. Perea, E. Angón, R. Arias, and A. Garzón. 2018. Coagulation efficiency and its determinant factors: A case study for Manchega ewe milk in the region of Castilla-La Mancha, Spain. J. Dairy Sci. 101:3878-3886.

Caravaca, F., J. L. Ares, J. Carrizosa, B. Urrutia, F. Baena, J. Jordana, B. Badaoui, A. Sànchez, A. Angiolillo, M. Amills, and J. M. Serradilla. 2011. Effects of $\alpha_{\mathrm{s} 1}$-casein $(C S N 1 S 1)$ and $\kappa$-casein $(C S N 3)$ genotypes on milk coagulation properties in MurcianoGranadina goats. J. Dairy Res. 78:32-37.

Cecchinato, A., and G. Bittante. 2016. Genetic and environmental relationships of different measures of individual cheese yield and curd nutrients recovery with coagulation properties of bovine milk. J. Dairy Sci. 99:1975-1989.

Chilliard, Y., A. Ferlay, J. Rouel, and G. Lamberet. 2003. A review of nutritional and physiological factors affecting goat milk lipid synthesis and lipolysis. J. Dairy Sci. 86:1751-1770.

Cipolat-Gotet, C., A. Cecchinato, M. De Marchi, and G. Bittante. 2013. Factors affecting variation of different measures of cheese yield and milk nutrient recovery from an individual model cheesemanufacturing process. J. Dairy Sci. 96:7952-7965.

Cipolat-Gotet, C., M. Pazzola, A. Ferragina, A. Cecchinato, M. L. Dettori, and G. M. Vacca. 2018. Technical note: Improving modeling of coagulation, curd firming and syneresis of sheep milk. J. Dairy Sci. 101:5832-5837.

Clark, S., and M. B. Mora García. 2017. A 100-Year Review: Advances in goat milk research. J. Dairy Sci. 100:10026-10044.

Fox, P. F., T. P. Guinee, T. M. Cogan, and P. L. H. McSweeney. 2017. Fundamentals of Cheese Science. 2nd ed. Springer, New York, NY.

Guinee, T. P., C. Gorry, D. J. O'Callaghan, B. T. O'Kennedy, N. O'Brien, and M. A. Fenelon. 1997. The effects of composition and some processing treatments on the rennet coagulation properties of milk. Int. J. Dairy Technol. 50:99-106.

Huppertz, T., and A. L. Kelly. 2006. Physical chemistry of milk fat globules. Pages 173-212 in Advanced Dairy Chemistry, Lipids. Vol. 2. 3rd ed. P. F. Fox, and P. L. H. McSweeney. Springer, New York, NY.

ISO-IDF (International Organization for Standardization and International Dairy Federation). 2013. Milk and liquid milk products. Determination of fat, protein, casein, lactose and $\mathrm{pH}$ content. International Standard ISO 9622 and IDF 141:2013. ISO, Geneva, Switzerland, and IDF, Brussels, Belgium.

Leitner, G., O. Krifucks, U. Merin, Y. Lavi, and N. Silanikove. 2006. Interactions between bacteria type, proteolysis of casein and physico-chemical properties of bovine milk. Int. Dairy J. 16:648-654.

McMahon, D. J., and R. J. Brown. 1982. Evaluation of Formagraph for comparing rennet solutions. J. Dairy Sci. 65:1639-1642.

Oftedal, O. T., and S. J. Iverson. 1995. Comparative analysis of nonhuman milks. A Phylogenetic variation in the gross composition of milks. Pages 749-789 in Handbook of Milk Composition. R. G. Jensen, ed. Academic Press, San Diego. CA.

Park, Y. W., and G. F. Haenlein. 2013. Milk and Dairy Products in Human Nutrition: Production, Composition and Health. WileyBlackwell, Ames, IA.

Pazzola, M., F. Balia, V. Carcangiu, M. L. Dettori, G. Piras, and G. M. Vacca. 2012. Short communication: Higher somatic cells 
counted by the electronic counter method do not influence renneting properties of goat milk. Small Rumin. Res. 102:32-36.

Pazzola, M., G. Stocco, M. L. Dettori, C. Cipolat-Gotet, G. Bittante, and G. M. Vacca. 2018. Modeling of coagulation, curd firming, and syneresis of goat milk. J. Dairy Sci. 101:7027-7039. https:// doi.org/10.3168/jds.2018-14397.

Pirisi, A., A. Lauret, and J. P. Dubeuf. 2007. Basic and incentive payments for goat and sheep milk in relation to quality. Small Rumin. Res. 68:167-178.

Poulsen, N. A., A. J. Buitenhuis, and L. B. Larsen. 2015. Phenotypic and genetic associations of milk traits with milk coagulation properties. J. Dairy Sci. 98:2079-2087.

Storry, J. E., A. S. Grandison, D. Millard, A. J. Owen, and G. D. Ford. 1983. Chemical composition and coagulating properties of renneted milks from different breeds and species of ruminants. J. Dairy Res. 50:215-229.

Sweetsur, A. W. M., and D. D. Muir. 1983. Effect of homogenization on the heat stability of milk. J. Dairy Res. 50:291-300.

Vacca, G. M., P. Paschino, M. L. Dettori, M. Bergamaschi, C. CipolatGotet, G. Bittante, and M. Pazzola. 2016. Environmental, mor- phological, and productive characterization of Sardinian goats and use of latent explanatory factors for population analysis. J. Anim. Sci. 94:3947-3957.

Vacca, G. M., M. Pazzola, M. L. Dettori, E. Pira, F. Malchiodi, C. Cipolat-Gotet, A. Cecchinato, and G. Bittante. 2015. Modeling of coagulation, curd firming and syneresis of milk from Sarda. J. Dairy Sci. 98:2245-2259.

Vacca, G. M., G. Stocco, M. L. Dettori, E. Pira, G. Bittante, and M. Pazzola. 2018a. Milk yield, quality and coagulation properties of six breeds of goats: Environmental and individual variability. J. Dairy Sci. 101:7236-7247. https://doi.org/10.3168/jds.2017-14111.

Vacca, G. M., G. Stocco, M. L. Dettori, A. Summer, C. Cipolat-Gotet, G. Bittante, and M. Pazzola. 2018b. Cheese yield, cheese-making efficiency, and daily production of six breeds of goats. J. Dairy Sci. 101:7817-7832. https://doi.org/10.3168/jds.2018-14450.

Vassal, L., A. Delacroix-Buchet, and J. Bouillon. 1994. Influence des variants $\mathrm{AA}, \mathrm{EE}$ et $\mathrm{FF}$ de la caseine $\alpha_{\mathrm{s} 1}$ caprine sur le rendement fromager et les caractéristiques sensorielles de fromages traditionnels: Premières observations. Lait 74:89-103. 